\title{
Formandens årsberetning 25. oktober 1991
}

Grundtvig-Selskabets årsmøde 1990 blev afholdt 9. november på Aarhus Universitet, Studenternes Hus (Richard Mortensens stue). Ved årsmødet talte Kirsten Ditlevsen om »Maria - et forbillede for kristne? Grundtvigs syn på Jomfru Maria «. Foredraget er senere trykt i Grundtvig-Studier 1991.

Inden årsmødet var den hidtidige sekretær i København for Grundtvig-selskabet, Peter Balslev-Clausen, af styrelsen blevet valgt som ny formand for selskabet i stedet for Christian Thodberg, der ønskede at træde tilbage fra formandsposten; Christian Thodberg fortsatte dog som medlem af forretningsudvalget med den særlige opgave at varetage forbindelsen med den norske afdeling af selskabet. Det foreløbige valg af Erik Jakob Petersen som ny kasserer for selskabet og medlem af forretningsudvalget blev stadfæstet. Regin Prenter havde på grund af sygdom ønsket at træde ud af styrelsen; i hans sted indvalgtes canon Arthur Macdonald Allchin, Oxford, i styrelsen. På genvalg til styrelsen var Gustav Albeck, K.E. Bugge, Flemming Lundgreen-Nielsen, Poul Kiilerich, Erland Jessen og Theodor Jørgensen, der alle blev genvalgt. Til forretningsudvalget blev Gustav Albeck og Hellmut Toftdahl genvalgt og Erik Jakob Petersen og Jens Holger Schjørring nyvalgt.

Samarbejdet med Center for Grundtvig-Studier ved Aarhus Universitet har siden sidste årsmøde udviklet sig på en for begge parter meget tilfredsstillende måde. 4.-6. april 1991 blev den gennem længere tid forberedte dansk-engelske Grundtvig-konference afholdt på Sct. Chad's College ved Universitetet i Durham. Konferencen blev afholdt som et bilateralt samarbejde mellem Center for Grundtvig-Studier og Center for the Study of Literature and Theology ved Universitetet i Durham og samlede en række engelske og danske forskere.

I lighed med Sandbjerg-konferencen året i forvejen kan dette ses som et udtryk for den stigende internationalisering af Grundtvig-forskningen. Andre udtryk for denne tendens er det 336 sider store bind med bidragene fra Grundtvig-konferencen i Köln 1988: »Um des Menschen willen« udgivet under redaktion af konferencens initiativtager og leder, Paul Röhrig. Dertil kommer Frans Grouwer's store disputats på hollandsk, »Vernieuwing in drieklank« (1990), der har et tyngdepunkt i Grundtvigs 
indsats som salmedigter og kirkemand, og Steven M. Borish's »The Land of the Living «, der beskæftiger sig med Grundtvigs kulturelle og pædagogiske betydning. To væsentlige danske bogudgivelser er dels Jens Holger Schjørring: „Grundtvigs billedsprog og den kirkelige anskuelse « (1990), dels et udvalg af Anders Pontoppidan Thyssens artikler og afhandlinger om Grundtvig og grundtvigianismen, »Grundtvig og den grundtvigske arv«, der blev udgivet $\mathrm{i}$ forbindelse med forfatterens 70 -års dag. I forbindelse med Anders Pontoppidan Thyssens 70-års dag blev der yderligere på Aarhus Universitet afholdt et todages seminar, der i høj grad bar præg af Pontoppidan Thyssens Grundtvigforskning. Selv har jeg udgivet en studiebog om Grundtvigs salmer med titlen »Det vingede ord «.

Det skal i denne forbindelse nævnes, at arbejdet med den tyske videnskabelige oversættelse af Grundtvig-tekster, planlagt til at omfatte tre bind, skrider planmæssigt frem.

Den norske afdeling af Grundtvig-Selskabet har igen i år været præget af stor aktivitet, ikke mindst takket være Dag Løkkes energiske indsats. Forbindelsen til den norske afdeling varetages som allerede nævnt af selskabets afgåede formand Christian Thodberg.

Grundtvig-Studier er igen i år blevet udsendt i et fornemt udstyr med en række artikler, der afspejler Grundtvig-forskningens store bredde. På Grundtvig-Selskabets vegne takker jeg N.F.S. Grundtvigs Fond og Statens humanistiske Forskningsråd for støtte til udgivelsen af Grundtvig-Studier 1991. 